Print ISSN 1997-9967 /online ISSN 2663-550X

МРНТИ 06.73.35, 06.73.65, 06.73.55

JEL: G21, G24, G1, G28

\title{
Financial technologies trends and the way they will shape financial markets
}

\author{
Bauyrzhan N.Kobadilov ${ }^{1}$, Galym B.Omarov ${ }^{2}$, Dinara D.Yermekbayeva ${ }^{3}$
}

\author{
Received: February 10, 2020 Revised: February 24, 2020 Accepted: March 09, 2020
}

\section{Түйін}

Финтех бүгінгі таңда халықаралық ғалымдар арасындағы өзекті тақырыптардың бірі болып табылады. Осы саладағы зерттеулерің көптігі пайдаланушыларға ақпараттық мөлшерден тыс ауыртпашылық тудырады. Зерттеудің мақсаты - зерттеу нәтижелерін ұйымдастыру және қолданылатын технологияларға байланысты сегменттер бойынша жіктелген, қаржылық технологиялар саласындағы жалпы бағыттарды анықтау. Зерттеу ғылымның келесі салаларын қамтиды: инновациялық зертханалар, платформалық бизнес, бұлтты шешімдер, ақшаны жылыстатуға қарсы ісқимыл, өзіңіздің клиентіңізді білу, блокчейн, реттеуші технологиялар және үлкен деректер. Мақала ғалымдар арасныдағы финтех анықтамасы аясындағы талқылаудан басталып, финтех мүмкіндіктерін жалпы сипаттаумен жалғасады. Финтех анықтамасы берілген соң авторлар осы призманың көмегімен трендтерді талдай бастайды. Зерттеу жеті негізгі тенденцияны анықтады: жылдамдық пен активтерді басқарудағы блокчейн артықшылықтарын іздеудегі қаржы нарықтары, реттеу және регтех сәйкестік мәселелерін шешуде, барлық тараптар үлкен мәліметтерге қол жеткізгісі келед, финтех саласының қатысушылары инновациялық зертханаларға көбірек қаржы бөлуде, бұлтты шешімдерді алу құны төмендеуде. финтех саласының ойыншылары бірігіп, бірлесіп жұмыс істеуде, финтех әзірлеушілері танымдылыққа ие финтех әзірлеушілеріне платформалар ұсынуда, өз клиентіңді біл ішкі процестерді автоматтандыру және ақшаны жылыстатумен күрес. Бұл саладағы әлемдік ғалымдар қауымдастығындағы ерекше белсенділік пен көптеген пікірталастар арқасында барлық аспектілерді қамту және финтех саласындағы барлық өзгерістерді ескере отырып қорытынды жасау қиындық туғызады.

Түйін сөздер: финансовый рынок, финтех, трендтер, блокчейн, РегТех, улкен деректер, банкинг.

\section{Аннотация}

В настоящее время исследования в области финтех - одни из самых популярных среди международных ученых. Обилие исследований в этой области приводит к тому, что пользователи страдают от информационной перегрузки. Целью данной работы является организация результатов исследования и выявление общих тенденций в области финансовых технологий, которые могут быть применены к сфере финтех, классифицированной по сегментам в зависимости от используемых технологий. Исследовательская работа охватывает такие области науки, как инновационные лаборатории, платформенный бизнес, облачные решения, борьба с отмыванием денег, знание своего клиента, блокчейн, регуляторные технологии и большие данные. Статья начинается с определения финтех и описания его возможностей. Нами проанализированы тенденции и выявлены семь основных: финансовые рынки в поисках преимуществ блокчейна в управлении скоростью и активами, регулирование и RegTech решают проблемы соответствия, все стороны хотят заработать на больших данных, участники отрасли финтех вкладывают больше средств в инновационные лаборатории, стоимость приобретения облачных решений снижается, консолидация и сотрудничество игроков отрасли финтех, разработчики финтех предоставляют платформы для разработчиков финтех: все больше и больше когнитивных вычислений используется в финансовых услугах, автоматизация внутренних процессов Know Your Customer и борьба с отмыванием денег. Из-за высокой активности и дискуссий в мировом сообществе ученых в данной сфере трудно охватить все аспекты и сделать выводы, которые учитывают все изменения, происходящие в области финтех, что подтверждает актуальность данного исследования.

Ключевые слова: финансовый рынок, финтех, тренды, блокчейн, РегТех, большие данные, банкинг.

\section{Abstract}

Today fintech research is among trending topics by international scholars. Abundance of research in this sphere causes state of infobesity for users. Goal of the research is to organize research findings and reveal general trends in fintech that can be applied to fintech sphere classified to segments depending on technologies used. Research work covers fintech areas such as: Innovation labs, Platform business, Cloud solutions, Anti Money Laundering, Know Your Customer, Blockchain, Regulatory technologies and Big Data. First, definition of fintech is discussed and fintech opportunities are analysed. Second, those fintech trends are generalised.. As a result seven general trends revealed: Financial markets in pursue of blockchain benefits in speed and wealth management, Regulation and RegTech solving compliance issues, All parties want to master big data, Participants of Fintech industry investing more in Innovation labs, Opportunity cost of acquiring cloud solutions decreasing, fintech industry players consolidating and collaborating, Fintech developers providing platforms for fintech developers, More and more cognitive computing is used in financial services, Automatization of Know Your Customer internal processes and Anti Money Laundering.

Key words: financial market, fintech, trends, blockchain, RegTech, Big Data, banking.

1 MSC, senior lector, University of International Business, Almaty, Kazakhstan, e-mail:kobadilov@mail.ru

2 Phd. Assistant professor, International university of information technologies, Almaty, Kazakhstan, e-mail:galym.omarov@gmail.com

3 Phd. Assistant professor, University of International Business, Almaty, Kazakhstan, e-mail:ermekbaevad@mail.ru 


\section{Introduction}

Today information technologies are widely used in finance area. The developments of application of information technologies lead to generation of financial technologies (fintech) research area. Fintech is comparatively young field of science regarding its popularity in financial markets in context of nowadays intensity of usage. Thus state of research in this area is not at the same level as other areas. However scholarly communities are very open to fintech which can be noticed from a lot of publications and speed of changes in this field. Main disadvantage in this situation is the difficulty of organization of information. More work is required in organizing scattered information in this area. In order to define fintech author refer to conversation of scholars on definition and finally uses definition of Financial Stability Board. Concerning main segments of fintech author uses the results of scholars and divides them as Aljouni and Al Hakim, and organizes the research according these segments

Goal of the research - to shed light to the question on ongoing trends in this field, concerning developers, disrupters, incumbents, traditional financial market organization and market shares, and direction of technology developments in fintech.

\section{Literature Review}

Firstly to answer research question it is obvious to define fintech and clarify understanding of fintech in this work. Scholars argue much precisely in defining fintech. Various works offer various definition of fintech [1]. [1] Literature review and methodical semantic analyses revealed 13 definitions of fintech that defined fintech as a financial sector, but not technology. [2], defined fintech as a sector in Finance that considers technologies to facilitate trade, business and services provided in retail. Because of fluidity of fintech developments, Basel committee of banking supervision (BCBS) decided to use more broad definition of fintech offered by The Financial Stability Board. FSB defines fintech as "technologically enabled financial innovation that could result in new business models, applications, processes, or products with an associated material effect on financial markets and institutions, and the provision of financial services." [3] So what is fintech? In other words, fintech is the use of advancements in information technologies that enables financial services more efficient, not only in terms of operation but also in terms of cost [4]. Scholars and reports on fintech industries defined opportunities fintech offer from different angles. Generally opportunities derived from subjects like: consumer security, market integrity, competition with traditional financial intermediaries, financial inclusion, automation and reap synergies from adoption of fintech in international markets [3]. According to comprehensive work in this question, opportunities can be classified as following: Consumer sector: Financial inclusion, Better and more tailored banking services, Lower transaction costs and faster banking; Banking: Improved and more efficient banking processes, Innovative use of data for marketing and risk management purposes, Potential positive impact on financial stability due to increased competition, Regtech services [5].

Due to research of [6] financial intermediation commission in US kept around 2 percent during past 130 years. And this research tries to check are fintech developments directed to reduce commissions and evaluate how trends are correlated with waiting and opportunities that fintech provides.

\section{Methodology}

This paper is a review of the literature in fintech with its application in financial markets. Study provides theoretical background to research question examines facts and statistics, and then reviews the findings and achievements in fintech sphere. The review is organized around main research problem. The paper summarizes our knowledge on this question and concludes with forecasts in fintech development.

\section{Findings and discussion}

Financial markets in pursue of blockchain benefits in speed and wealth management

Fintech to a greater extent draws its technological achievements from the blockchain technologies. Blockchain technologies mainly associated with cryptocurrency Bitcoin, but actually Bitcoin is just build on blockchain technology and actually only one of the limitless appliances of blockchain technologies in fintech sphere. Blockchain technologies are technology that supplies banking financial technologies with different hacks and chips that is changing dramatically banking operations in terms of speed and costs [7].

Last five years are full of argues on blockchain technologies. Blockchain technologies became popular after emergence of cryptocurrency trading. Among cryptocurrencies Bitcoin is the most popular, but in essence bitcoin is the one product of blockchain technology. Blockchain found its appliance in a lot of other products and services. For example in USA Blockchain is used in settlements process in stock trading companies. Traditional settlement process requires 3 days of money transfer from buyer to seller of stock [8]. With blockchain this transfer can be made immediately and save 3 days, which is really big time arbitrage for traders and chance to earn more from reinvestment. It was known in World Economic Forum that 10 trillion dollars 10 percent of the global GDP 100 trillion dollars will be formed by blockchain technologies till 2027. All this funds, if it would be made to startups, of course will change investment facilities [9].

Banks also experimented with blockchain technologies as a way to speed up the back office. According to some industries, this can reduce costs 
by $\$ 20$ billion. Thus, financial technologies become very good investment opportunity for last several years. Recently, a beta version released on last version of the IBM Worldwire blockchain network. The service uses the stellar protocol and enables financial institutions clear international payments in seconds. In other words, blockchain can improve the question of compliance here. As a rule, transactional payments between banks are resolved through the complex relationships of correspondent banks. However, with the help of this blockchain system of Worldwire, financial institutions use the so-called stable coin or some other digital currency as a bridge between fiat currencies, which noticeably decrease transfer time and costs. In addition, the growth of transactions in stable coins can be the main indicator of growth or a boom in the definitions of the next dominant cryptocurrency [10].

In partnership with Chain, NASDAQ and City tested the use of blockchain technology to buy and sell shares in a private company. This partnership ideologically competes with the NASDAQ platform and Link, which processes a trillion dollars a year worldwide. The projects are called Treasures and Trade Solution presented by the City group. This is a very promising project [11].

Despite GP Morgan CEO Jamie Dimon calling Bitcoin a scam, the bank is actively testing the use of blockchain technology. He recently submitted a patent for using distributed ledger technology to handle transactions between banks. That is, again, means that banks are investing precisely in the blockchain technology [12]. Using this technology provides audit transparency for the transaction, presenting you with the opportunity to process payments in almost real time. Previously it was impossible; as a result document flow was is in a very slow state. We do not mean cash transactions right now. For example, nowadays the Visa system or MasterCard make transactions faster than on blockchain technology [13]. Nevertheless, interbank transactions, which are still very, slow precisely because of the workflow. On behalf of this problem, this area is becoming increasingly interesting for investor banks.

Syndicated loans are loans provided by a group of lenders to a single borrower and they often rely on sending large volumes of documents between different companies. To simplify this, BBVA Bank uses the blockchain technology [14]. BBVA was able to organize a loan platform that joins all parties, as lenders and borrowers together and in this way bank reduced time needed for communication of parties.

Moreover on investments, Goldman Sachs creates in New York a trading platform with a cryptocurrency that will work by the end of 2019, but so far it is still in the test version [15].

Blockchain distributed ledger technologies is one of the most important technologies on the basis of which new fintech innovations arise. Blockchain became popular after emergence of cryptocurrencies. However, according to many analysts, cryptocurrency is unlikely to gain a foothold as a basis in the markets due to its volatility and uncertainty regarding viability. In general, it is difficult to imagine it as a carrier of value, that is, it is not clear how much it should cost [8]. The blockchain presents to non-banking entities a proven easily generated online indication. Hereby, in this direction the basic technologies will develop with consequent implementation in banking business processes. This is why a lot of startups are developing and seeking their chance in this niche. issues

Regulation and RegTech solving compliance

According to analysts, there is a very large flow of investment to this segment. Investments in RegTech are likely to increase by $500 \%$ in 2020 [16]. That is, a very serious infusion made because it will lead in essence to simplification of compliance. It is to simplify the work of the bank itself. In other words, it is optimization of work due to the introduction of high technologies, monitoring and defecation registries, real-time transaction compliance and etc. [17].

The payment services directive, the so-called Payment Service Directive Two (PSD2) - regulatory directive of the European Union. It aims to increase competition in the European payment industry. At the same time, the concept of open banking based on PSD2 has spread internationally and will contribute to the development of the entire fintech sector. In particular, it is strengthening consumer protection and the desire to create legitimate competition. In general, this directive is already being applied in the European Union and the fact that it is accepted by the international community as a standard of regulation in this area, leads to the development of new financial technologies, and most importantly, they will be introduced soon [18].

European banks represented by Swiss banks UBS Barclays and Credit Suisse are now piloting a platform based on the Ethereum technologies. Swiss Banks are leading this pilot project, aim to automate regulatory requirements for the rules of MiFit2 or Mifir. This is the EU regulation that came into force in 2018. Using the created system, based on Ethereum technology, bank participants will be able to anonymously cross-reference the data of a legal entity. This greatly reduces the cost and accelerates the issue of compliance and the issue of transfers [19].

However, regulations in information confidentiality are still serious problem for fintech startups [20]. Alibaba shows incredible results in entering to financial markets of Asia with its fintech giant Ant Financial. Google trying to share market with Ant Financial and relies on its startup Google Pay, but limitations with information confidentiality of customers became serious impediment to such companies. 


\section{All parties want to master big data}

Today big data is in trend and the reason is the information in abundance that banks struggle to work with. Big data is the technologies where machines can pass through themselves vast amount of information and more important is that they can find valuable information for your business purposes. Intelligence search companies can achieve this result despite their location if the proper classification is applied at storage processes. Traditional banking assumes hiring a lot of professional analysts that research the specific industry in order to make recommendations to traders or sales managers that result in higher revenues from their perspective clients [21]. Today machine can process really huge amount of information that accounts for last 10 years or even 100 years and show some patterns that with high probability tend to repeat. For example, if we see pattern that stocks of specific companies rise during first week after the elections and if to buy stock of the company from this industry with market capitalization of 10 billiards dollars and hold them for 5 years we can make on average 7 percent return. These services are popular and now we have companies that offer intelligence research using big data [22].

China's fintech success story consists of fintech developments, which built on customer platforms of giant companies as Alibaba. Ant Financial, Alipay, Yu'e bao, Alipay wallet, Mybank and Tencent -all of them fintech companies that were raised on behalf of this platform built fintech development model [23] Thus, companies like Apple and Amazon with strong consumer platforms can cause big problems by starting their fintech companies. Incumbents in turn should exploit big data they have to their own benefits [24]. However, they should be again cautious with customer information confidentiality issues.

Participants of Fintech industry investing more in Innovation labs

Today traditional financial institutions become more open to changes and many organizations establishing innovations labs. Previously companies were doing their researches in $R \& D$ departments, but today, companies focus heavily on technologies, and research in this sphere become more organized and directed. Research shows that, almost 80 percent of companies own innovation labs at their premises. R\&D spending in 2018 by 100 largest corporations added 11.4 percent and equaled to $\$ 782$ billion [25]. Research shows that those who own innovation labs or innovation teams likely to create at least one innovative product or innovative technology during three years [26]. Innovation labs also established in universities collaborating with business. Business address to innovation labs tasks such as development of new products or niche that can be next unicorn in finance sphere.

The rate on the development of new $R \& D$ technology in this sector is increasing for major banks and this is happening everywhere. GP Morgan Chase, in October 2017 bought the VPAY payment system and after that the number of so-called workers, engineers who develop this technology began to grow sharply. This suggests that the company is hiring new technologists, new engineers, but also increasing its potential in this sector in payment system technology. In any case, this will result in the emergence and implementation of new technology and the optimization of the banking business itself [27]. The same GP Morgan Chase in the near future will work more optimally, will reduce costs, increase profitability, and so on, these are all consequences of the fact that the company focuses more on new technologies; otherwise it would not be observed.

Opportunity cost of acquiring cloud solutions decreasing

Nowadays banks try to transform and keep their data in cloud solutions. Historically all data which results from business operations was saved in servers at own premises of organization. Banks spent huge amount of their investment resources to acquire hardware that was used to store data on transactions and information about their customers. Moreover, they were obliged to keep all of this for duration starting from 5 to 10 years. Today accessibility and less cost to acquire cloud computing enabled banks to welcome this emerging technologies. This lead to immediate cut in server and hardware expenses that were used to store the info. Besides, popularization of cloud computing technologies ignites the development of cloud computing related software [28].

Another reason for changes in this sphere is the developments in cybersecurity in cloud computing. Earlier companies were unwilling to embrace new technologies because they were afraid of leak of confidential information. Enhancements in cybersecurity in cloud computing made decision makers more positive in acquiring cloud computing [29].

\section{Consolidation and collaboration of fintech industry players}

As another trend in financial technologies industry is the consolidation of vendors. Ordinary bank usually has many information suppliers. Suppliers outsource information organization process. Banks want to join more operations as possible to less quantity of suppliers and programs. This gives good opportunity to vendors that can cover more bank operations in their software solutions. Usually Customer Relationship Management (CRM) and Enterprise Resource Planning (ERP) system developers suit this requirement best. A CRM system usually starts from front office affairs. For example sales managers start its case by using help desk in CRM system that consequently goes to analysts and managers for optimizing of business processes. Meanwhile, an ERP system such as Session Initiation Protocol (SIP) helps companies to enhance back office operations. 
For example to generate invoice, transfer payments to vendors, check 3rd parties that partner with company. That is, then this two systems work with each other and in this way can cover as many as possible bank operations. As a result bank operates with least quantity of software suppliers that enables them to focus more on operations that generate revenue. For banks in terms of profitability it is meaningless to interrelate with operators which figure between sales and settlement operations, rather than seeking and stressing more priority operations [30].

Fintech companies understand that they reached the point where they cannot survive just using technologies and trying to seek friends among giant traditional companies. Fintech has speed of adaptation; traditional financial institutions risk bearing methodology and third party giant companies like Alibaba has their broad client base. Moreover, bargaining power of incumbents regarding regulation problems, which scare and block fintech companies from entering markets, is the critical point for collaboration between all parties. However, most important is the fact that, every party has something that is wished by other. Many financial institutions already report in their strategies collaboration with fintech developers. Collaboration also performed through organizing fintech hubs and technological investment parks were developers despite their sizes can conduct with each other. However, China applying different approach that exclude junior companies. Government requires biggest banks for collaboration with fintech giants, which in turn form ecosystem with giants like Alibaba with biggest customer base. Applying this strategy enabled China to create ecosystem that generated more startups that offer full range of fintech services comparing to Western developers [31].

Fintech developers providing platforms for fintech developers

Two companies that lead in CRM and ERP systems are Sales force and Microsoft Dynamics. Last is developing rapidly its hybrid solutions that is capable to store information not only cloud but also at premises. Biggest ERP system in the world is SIP. Oracle is also has its own portion in information storage providers market. Because of their expertise in data storage technologies above mentioned companies hold bigger portions of the market. Sales force accounts for 19 percent of the market [32]. Despite being leaders in this market company wanted to widen the coverage of operations in terms of functionality. It gave start to platform business models and later started to use open platform. Open platform gives opportunity to outside developers access, work and develop products and Salesforce systems is no exception. Sales force has three type of products- Sales cloud (healthcare industry), Sales CRM and Service cloud Marketing Cloud (helps to marketing dep). Service cloud developed a platform which is named Sales force app exchange which enables developers to access standard functions of sales force and develop further programs that will support sales force and has value to specific customers or and specific industries [33]. For example IPhone user can download apps like Yandex Navigator from outside developers which are developed on Apple IOS platform but actually do not work for Apple Inc. Another example Uber offers platform for taxi drivers for 20-30 percent from revenue compensation and covers all costs for development and support for platform. In this case taxi drivers happy to share gross margin with platform developers in exchange for extra revenue. Same situation with developers that outsource each other, research shows that 87 percent of companies are ready to work with platform in order to increase their revenues using alternative ways [34].

More and more cognitive computing is used in financial services

Cognitive computing is the production of processes by using in advance defined algorithm and assumes no human relation [35]. Today typical operations are converting to automatization. Before managers used to fill invoices and print it out with further signing, but now, you report sale on CRM system and after one cycle the same operation is generated automatically and if the case is subscription business, operation will repeat with no human interaction depending on your contract terms [33]. Artificial intelligence, the so-called robotic process automation, attracting a very large investment of countries and major players because the technology that can replace the tedious work. That is, where previously a person used to pick up in Excel, a robot can perform same volume of work in seconds. This automation leading to a sharp reduction in the number of bank employees and, accordingly, sharply reduces the costs of banks and increases the processing speed of everything. In other words, the speed of internal processes at banks increases, costs are reduced [36]. Economists have calculated that companies that use these Robotic Process Automation (RPA) technologies, now have a ROI (return on investment) ranging from 40-100 percent within 3-8 months after launch. That is, RPA technologies such a profitable opportunity that banks all over the world, soon will start to invest altogether in this technologies and this will lead to rapid changes in fintech industry in the coming years [37].

Another trend in financial technologies is the Robo-advisers that used instead of invest consultants. Today millennials can use services of the bank without having a trip to bank. All of the interactions and communication with bank and other financial intermediaries are can be done using mobile phones [38]. For example, investor living in San Francisco that prefers to invest to specific fintech company from Silicon Valley that develops fintech programs which has market capitalization of 10 billiard can communicate his idea to the company and access robo-adviser. 
Then, after automatic search when robo-adviser finds alternative it can report company's proposal that best suits potential investor's preferences. Robo adviser became popular among investing houses [39].

Although, Robo advisors automated consulting process and in online ordering, cognitive computing already substituting them with Robo analysts in light of millennials unwillingness of independent decision making behavior [40].

Automatization of Know Your Customer internal processes and Anti Money Laundering

Next trend is the automatization of KYC internal processes. Manager who is working with perspective client can check client for fraud history and if client has sanctions or not. To do this manager can mention that his company does not prefer to collaborate with fraud related parties and thus activate algorithms that check subject for fraud history. Moreover, with the help of automation, banks now can be alerted against money laundering activities. For example, if bank notices that the same amount of money, at same time, transfers from the same source to the same recipient with iteration, bank cyber security system start to alert about money laundering activity. Especially if it happens in the country which has such precedent, banks secrecy or compliance officer can suspend and stop such transaction and accept it as fraud [41].

\section{Conclusion}

To sum up trends in financial technologies, can be assumed that Blockchain technologies will evolve, but it will develop precisely in specific sectors [42]. Moreover, it can be assumed that most innovations in financial technologies industry will be based largely on blockchain technologies. But with regard to cryptocurrency, it is not expected that there will be some kind of boom or emergence of a new dominant cryptocurrency. Because, cryptocurrency is by and large, one of the products based on blockchain technology, nothing more. The blockchain technology itself is interesting for financial market participants. For example, Etherium team introduced etherium cryptocurrency and plus, there is an etherium platform. Etherium platform has not only the technology of the currency itself on which to build the currency, but also which allows you to build exactly new applications, new technologies [43]. For example, UBS credit banks, now making their solutions on the etherium platform. Thus, it is obvious that etherium will continue to specialize in technology earnings, and will not be perceived as just cryptocurrency like it is now perceived by the bulk. Perhaps, cryptocurrencies will remain in some form, but for certain payments. In near future, it will probably be created several or just one working currency. Maybe it will be ripple or some other currency, but most likely it will still be ripple. Ripple was originally created by a consortium of banks and hence it is stable coin without any other missions [44]. Ripple can be used as bridge or exchange currency for fiat currencies. Then, ripple is quickly transmitted overseas and there it will be reverted accordingly. If connect compliance technology based on the blockchain and other financial technology capabilities that are currently being developed and already being introduced, then this will drastically reduce costs, drastically reduce the need for staff and increase the profitability of banks and the speed of payments increases [44].

Concluding the other trends it can be noticed that development of fintech is accelerating and decrease in opportunity cost of acquiring fintech along with new technologies emerging makes it easy to find new niches for more earnings. Yesterday's trends as Big Data and Platform business become "cash cows" for financial market. Investors prefer to develop and use fintech more widely comparing to previous years. For example despite low usage of AI for revenue generation, key investors didn't stop investing to cognitive technologies. Moreover they diversifying their investments and buying promising disrupters together with their ideas and technologies. All this changes in the market, point out the best way to develop fintech in less developed countries. Fintech success stories show that fintech pays off to those who approach investing carefully.

\section{References}

1. Schueffel P. (2016). Taming the beast: a scientific definition of fintech. SSRN Electronic Journal 4(4), 3254.

2. Micu I. \& Micu A. (2016). Financial Technology (Fintech) And Its Implementation On The Romanian NonBanking Capital Market // SEA-Practical Application of Science(11), 379-384.

3. FSB. (2019). Financial stability Board https://www. fsb.org/work-of-the-fsb/policy-development/additionalpolicy-areas/monitoring-of-fintech/. Accessed in 07.2019.

4. Thakor. (2019). Fintech and banking: what do we know? // Journal of Financial Intermediation, 3.

5. Al Ajlouni, Ahmed \& Al-Hakim, Monir. (2019). Financial Technology in Banking Industry: Challenges and Opportunities.

6. Philippon T. (2018). Has the US Finance Industry Become Less Efficient? On the Theory and Measurement of Financial Intermediation" // American Economic Review, 105 (4), 1408-38.

7. Okina Y. \& Aoki S. \& Cho T. (2017). Understanding the Essence of FinTech and Leveraging It for Innovation in Finance,

8. Bhandarkar V., Bhandarkar A., Shiva A. (2019). Digital stocks using blockchain technology the possible future of stocks? // International Journal of Management (IJM) Volume 10, Issue 3, 44-49.

9. Heinonen H. (2018). Internet of Things booming 15 Trillion Market // Towards data science.

10. IBM. (2019). Retail CBDCs: The next payments frontier // Blockchain worldwire Report. Retrieved from https://www.ibm.com/blockchain/solutions/world-wire Accessed in 07.2019.

11. Wells R. (2015). NASDAQ and CHAIN to partner on blockchain technology initiative // Nasdaq media,. retrieved from http://ir.nasdaq.com/news-releases/news- 
release-details/nasdaq-and-chain-partner-blockchaintechnology-initiative Accessed in 08.2019.

12. Cheng E. (2017). Jamie Dimon is betting big on the technology behind 'fraud' bitcoin CNBC, Retrieved from https:/www.cnbc.com/2017/10/16/ jpmorgans-dimon-betting-on-blockchain-even-as-he-callsbitcoin-stupid.html Accessed in 08.2019.

13. Li K. (2019). The Blockchain Scalability Problem \& the Race for Visa-Like Transaction Speed.

14. Karppinen U. (2018). BBVA signs world-first blockchain-based syndicated loan arrangement with Red Eléctrica Corporación., Retrieved from https:// www.bbva.com/en/bbva-now-offers-offers-sustainablefinancial-contracts-to-individual-customers/ Accessed in 08.2019.

15. Tannam E. (2018). Goldman Sachs says it's still working on creating a cryptocurrency trading desk // Silicon republic.

16. BBVA Open4U (2018). Six notable trends for the Fintech sector.,. Retrieved from https://bbvaopen4u.com/ en/actualidad/six-notable-trends-fintech-sector Accessed in 08.2019 .

17. Szakiel P. (2018). FinTech Trends in 20190. Retrieved from https://www.bahrainfintechbay.com/singlepost/2018/12/23/FinTech-Trends-in-2019 Accessed in 08.2019 .

18. Accenture. (2018). Global Venture Capital Investment in Fintech Industry Set Record in 2017, Driven by Surge in India, US and UK // Accenture Analysis Finds.,. Retrieved from https://newsroom.accenture. $\mathrm{com} /$ news/global-venture-capital-investment-in-fintechindustry-set-record-in-2017-driven-by-surge-in-india-usand-uk-accenture-analysis-finds.htm Accessed in 08.2019.

19. Castillo M. (2017). UBS to Launch Live Ethereum Compliance Platform, Coindesk, Retrieved from https:// www.coindesk.com/ubs-launch-live-ethereum-platformbarclays-credit-suisse Accessed in 08.2019.

20. Harroch R.D. \& Guzy M. ( 2019). 10 Key Issues For Fintech Startup Companies Forbes, Retrieved from https://www.forbes.com/sites/allbusiness/2019/10/12/ fintech-startup-companies-key-challenges/\#39bf269a3e45 Accessed in 08.2019.

21.Whitney L. (2017). Are Computers Already Smarter Than Humans? // Time, Retrieved from https:// time.com/4960778/computers-smarter-than-humans/ Accessed in 08.2019.

22. Raju R.N. (2019). Do Elections affect the Stock Market? Retrieved from https://towardsdatascience.com/ do-elections-affect-the-stock-market-c28562646c71 Accessed in 08.2019.

23. McKinsey. (2018). Synergy and disruption: Ten trends shaping fintech, 5.

24. Dryer. (2019). What Bank Customers Actually Want From Big Data // Forbes, https://www.forbes. com/sites/forbesfinancecouncil/2019/09/09/five-trendsshaping-fintech-into-2020/\#732614ed2f13 Accessed in 08.2019.

25. Bodniece K. (2019). 76 surprising facts about corporate innovation, Valuer.

26. Indicative (2019). The 6 Ways The Biggest Companies Are Fighting Back Against Silicon Valley Retrieved from https://www.indicative.com/blog/unicornsvs-titans-industry/

27. Indicative. (2019). Unicorns vs Titans. Valley Retrieved from https://www.indicative.com/blog/unicornsvs-titans-industry/ Accessed in 09.2019.

28. Dimon J. (2017). JPMorgan Chase \& Co. Annual Report.

29. Walker A. (2018). Everything You Need to Know About Cloud Computing. Retrieved from https://learn. g2.com/cloud-computing Accessed in 09.2019.
30. Teplinsky M.J. (2013). Fiddling on the Roof: Recent Developments in Cybersecurity, 2(2), 239

31. Paul L.G. (2014). Erp consolidation: and then there was one. Techtarget, 7 .

32. McKinsey. (2018). Synergy and disruption: Ten trends shaping fintech, 5 .

33. Columbust L. (2019). Salesforce Now Has Over 19\% Of The CRM Market, Forbes. Retrieved from https:/www.forbes.com/sites/louiscolumbus/2019/06/22/ $\mathrm{s}$ a le s for c e - n o w - h a s - ove r - 19 - of - t h e - c r m market/\#6c04f80c333a Accessed in 09.2019.

34. SF. (2018). Retrieved from https://c1.sfdestatic. com/content/dam/web/en us/www/documents/pricing/ DS_SalesCloud_EdCompare.pdf Accessed in 09.2019.

35. Magne S. (2017). Report: 87 Percent of Business Leaders Say Company's Success Depends on Ability to Connect with Customers via Cloud Communications. Retrieved from https://www.businesswire.com/news/ home/20170926005649/en/Report-87-Percent-BusinessLeaders-Company $\%$ E2\%80\%99s-Success Accessed in 10.2019 .

36. Makadia M. (2019). What is Cognitive Computing? How are Enterprises benefitting from Cognitive Technology? Retrieved from https://towardsdatascience. com/what-is-cognitive-computing-how-are-enterprisesbenefitting-from-cognitive-technology-6441d0c9067b Accessed in 10.2019.

37. Relx. (2019). Adoption of AI technologies among US businesses increases from $48 \%$ to $72 \%$ in one year, according to RELX. Retrieved from https://sciencebusiness. net/network-updates/adoption-ai-technologies-among-usbusinesses-increases-48-72-one-year-according Accessed in 10.2019 .

38. Szakiel P. (2018). FinTech Trends in 2019. Retrieved from https://www.bahrainfintechbay.com/singlepost/2018/12/23/FinTech-Trends-in-2019 Accessed in 10.2019 .

39. Marous J. (2017). The Rise of the Digital-Only Banking Customer, The financial brand.

40. Lochy J. (2019). Digital Investment Advice Should Financial Advisors start looking for another job? Finextra. Retrieved from https://www.finextra.com/ blogposting/17691/digital-investment-advice---shouldfinancial-advisors-start-looking-for-another-job Accessed in 10.2019 .

41. Trainer. (2017). Why Robo-Analysts, Not Robo-Advisors, Will Transform Investing, Forbes, Retrieved from https://www.forbes.com/sites/ greatspeculations/2017/07/19/why-robo-analysts-notrobo-advisors-will-transform-investing/\#4570103f6e39 Accessed in 10.2019.

42. Acimovic I. (2019). How blockchain transforms banking and financial services, FinTech Futures. Retrieved from https://www.fintechfutures.com/2019/11/howblockchain-transforms-banking-and-financial-services/ Accessed in 10.2019.

43. DI. (2019). Blockchain technology is broadly scalable and will eventually page 5 // Deloitte Insights,.

44. Radocchia S. (2017). How Is Ethereum Different From Bitcoin? // Forbes.

45. CT. (2019) What Is Ripple. Everything You Need To Know. https://cointelegraph.com/ripple-101/what-isrippleAccessed in 10.2019. 
/ Экономика: стратегия и практика, № 2 (15), 20202. 